\title{
DISCUSSION
}

\section{Experimental evaluations of stabilisation methods for sulphate-rich expansive soils}

\author{
A. J. PUPPALA, E. WATTANASANTICHAROEN and K. PUNTHUTAECHA, \\ (2003) Ground Improvement, 7, No. 1
}

\section{D. Higgins,}

\section{Cementitious Slag Makers Association, UK}

The authors are to be congratulated on their extensive investigation. However, I should like to make two comments.

In the section entitled 'Ground granulated blastfurnace slag' the authors state: 'Blast furnace slag is a by-product of iron production, and is formed by the combination of the siliceous constituents of the iron ore with the limestone flux used for smelting iron (Sherwood, 1995). Chemically, this slag has a composition similar to that of Portland cement.' Unfortunately they seem to have missed the subsequent sentence that appears in their quoted reference, namely: 'It is not in itself cementitious but it possesses latent hydraulic properties which can be developed by the addition of an activator such as lime or another alkaline material.' From their paper, it would appear that they used ground granulated blastfurnace slag (GGBFS) without any activating agent such as lime or cement. In other references that they subsequently quote, and in normal site practice (Higgins and Kennedy, 1999), GGBFS is activated by lime. Higgins et al. (1998) have reported that soils stabilised with GGBFS alone developed insignificant strength in comparison with those stabilised with GGBFS activated by lime. Adding an activator would have markedly enhanced the performance of their GGBFSstabilised mixes and reduced their deduced dosage level for field treatments, to much less than the recommendation of $20 \%$. Additionally, it has been reported (Wild et al., 1999) that, although GGBFS + lime is very effective at preventing ettringite expansion, the same may not be true when GGBFS is used alone.

In the section entitled 'Sulphate-resistant cement stabilisation' the authors suggest that stabilisation with Type V sulphate-resistant cement will not lead to ettringite formation. This has been investigated previously by Sherwood (1962), who found that 'substitution of sulphate-resisting cement for ordinary Portland cement did not reduce the disintegrating effect.' Ettringite is a calcium sulphoaluminate hydrate. In concrete, the only significant source of aluminate available to form ettringite is the calcium aluminate $\left(\mathrm{C}_{3} \mathrm{~A}\right)$ in Portland cement. Sulphate-resistant cement is manufactured to have a low (or zero) $\mathrm{C}_{3} \mathrm{~A}$ content, and in concrete this is effective in limiting ettringite formation. However, in stabilised soils, the clay fractions can readily contribute the aluminate required for ettringite formation. Consequently the use of sulphateresistant cement does not provide protection in the case of stabilised soils.

\section{Authors' reply}

The authors would like to thank the discusser for his interesting and informative comments on their paper. Regarding the first comment, the authors used ground granulated blastfurnace slag (GGBFS) alone without other chemical additives as this material has been recommended as a cementitious material (either by itself or with other additives) by the GGBFS providers in the USA (Slag Cement Association, 2004). Based on the percentage amounts of calcium in the material, the authors felt that it would provide effective stabilisation, without the need to mix it with another stabiliser. The strength properties measured in our research studies showed that this material provided significant enhancements to all four control soils.

The authors agree with the discusser's comment that the addition of an activator would have markedly improved the properties of the soils. However, this study did not focus on this aspect: hence this discussion focuses on GGBFS-treated soils only. Regarding swelling, we found that GGBFS alone did not result in sulphate heave in the studied soils. We attribute this to several causes, one of them being the pore size of compacted soils, which might have played an important role in mitigating ettringite heave in our soils. Further research on the mineralogy and micropore size distribution in soil could suggest potential causes of the reduced heave in these soils.

Regarding the second comment, we have two experimental studies, including the present research, which address sulphate-resistant cement stabilisation in sulphaterich soils: both studies show substantial reductions in soil heave. By contrast, sulphate soils treated with either lime or ordinary Portland cement (Type I) exhibited large amounts of heave. The amount of alumina (which we term 'reactive alumina') available in a treated soil will play a major role in the formation of ettringite and subsequent sulphate heave. Reactive alumina is the free alumina that is available for reactions with chemical species in soils. We agree with the discusser's comments on the presence of alumina in concrete materials. However, the statement that clay particles readily contribute alumina is still unclear, as the dissolution of alumina in clay minerals depends on the clay mineralogy, $\mathrm{pH}$ conditions and environmental soil conditions. In ongoing research, we found that the amounts of reactive alumina released from kaolinite, illite, montmorillonite, amorphous alumina and aluminosilicates, and organically bound alumina, are different. Therefore the amount of reactive alumina released from these minerals plays an important role in ettringite formation in the clays. 
Potential causes for the reduction of sulphate heave with sulphate-resistant cements are the reduced amounts of reactive alumina and sulphate available in soils treated with sulphate-resistant cement, which are far less than those in soils treated with ordinary Portland cement (since Type I cement provides certain amounts of alumina for ettringite reactions). Other potential reasons are changes in the porosity and permeabilities of treated soils, which do not allow room and moisture access for ettringite formation and growth (Puppala et al., 2004). In the authors' opinion, the two factors (reduced alumina dissolution from aluminium-bearing minerals because of decreased surface area due to compaction of clay minerals, and low permeability) should occur for reductions in sulphate heave.

We thank the discusser for his informative comments, which will lead to further advances in soil heave mechanisms and mitigation through experimental studies, particularly focusing on the chemical, mineralogical and microstructural aspects of soils treated with GGBFS and sulphate-resistant cement.

\section{References}

Higgins D. D. and Kennedy J. (1999) Lime + ground granulated blastfurnace slag stabilisation of boulder clay on the A421 Tingewick Bypass. 3rd European Symposium on the Performance and Durability of Bituminous Materials and Hydraulic Stabilised Composites, Leeds, UK.

Higgins D. D, KinUthia J. M. and Wild S. (1998) Soil stabilisation using lime-activated ground granulated blastfurnace slag. Proceedings of the 6th CANMET/ICI International Conference on Fly ash, Silica Fume, Slag and Natural Pozzolans in Concrete, Bangkok, 1057-1073.

Puppala A. J., Griffin J. A., Hoyos L. R. and Сhomtid S. (2004) Studies on sulfate resistant cement stabilization methods to address sulfate induced heave problems. ASCE Journal of Geotechnical and Geoenvironmental Engineering, 130, No. 4, 391-402.

SHerwood P. T. (1962) The effect of sulphates on cement-and limestabilised soils. Roads and Road Construction, 40, No. 470, 34-40.

Slag Cement Association (2004) http://www.slagcement.org/

Wild S., Kinuthia J. M., Jones G. I. and Higgins D. D. (1999) Suppression of swelling associated with ettringite formation in lime-stabilised sulphate-bearing clay soils by partial substitution of lime with ggbs. Engineering Geology, 51, 257-277 